\title{
DESIGN AND DEVELOPMENT OF DRIP IRRIGATION SYSTEM SOFTWARE IN VISUAL BASIC
}

\author{
K. HEMA NARAYANA REDDY ${ }^{1}, K$. ANIL KUMAR ${ }^{2} \&$ M. V. RAMANA ${ }^{3}$ \\ ${ }^{1,2,}$ P G Student, College of Agricultural Engineering, Madakasira A.P. India \\ ${ }^{3}$ Professor College of Agricultural Engineering, Madakasira A.P, India
}

\begin{abstract}
Drip irrigation system is the method of applying uniform and precise amount of water directly to the root zone of the plants as per the requirement, through emitters at frequent intervals over a long period of time, via a low-pressure pipe network comprising of mains, sub mains \& laterals. various software's were available for design and development of drip irrigation system. In the present project, it has been attempted to design the drip irrigation system using Visual Basic.NET as part of B. Tech (Ag. Engg) project. This attempt builds up the confidence levels of young engineers to work and design any type of irrigation system as per the need. Software for the design and development of drip irrigation system was developed with visual basic software based on all designing parameters. A sample run was made with assumed data for different crops. For Apple crop with a spacing of $15 \mathrm{ft} x$ 15ft requires $1 \mathrm{hp}$ pump with total head of $38.5 \mathrm{~m}$ should be operated for 2.5 hrs, flow in main line is 2.116402 lph costs about 97009 Rs. per ha. For Banana crop with spacing of $10 f t x 10 f t$ requires $3 \mathrm{hp}$ pump with total head of $38.5 \mathrm{~m}$ should be operated for $1.25 \mathrm{hrs}$, flow in main line is $4.938272 \mathrm{lph}$ costs about 120990 Rs. Per ha. For Coconut crop with spacing of 20ft $x 20 f t$ requires 1 hp pump with total head of 38.5m and should be operated for 5 hrs, flow in main line is 1.20120 lph and costs about Rs. 83417 Per ha. For Mango crop with spacing of 25ft $x$ 25ft requires $1 \mathrm{hp}$ pump with total head of $38.5 \mathrm{~m}$ and should be operated for 4.06 hrs, flow in main line is 1.532567 lph and costs about Rs. 77573 Per ha. For Pomegranate crop with spacing of 15ft x 15ft requires 1 hp pump with total head of $38.5 \mathrm{~m}$ and should be operated for $2.5 \mathrm{hrs}$, flow in main line is 2.116402 lph and costs about Rs. 120990 Per ha. For Orange crop with spacing of $18 f t x 18 f$ t requires 2 hp pump with total head of 38.5m and should be operated for 1.88 hrs, flow in main line is 2.962963 lph and costs about Rs. 92940 Per ha.

KEYWORDS: Drip Irrigation \& Visual Basic.NET
\end{abstract}

Received: Jun 24, 2017; Accepted: Jul 13, 2017; Published: Jul 19, 2017; Paper Id.: IJASRAUG201742

\section{INTRODUCTION}

Drip irrigation system is the method of applying uniform and precise amount of water directly to the root zone of the plants as per the requirement, through emitters at frequent intervals over a long period of time, via a low-pressure pipe network comprising of mains, submains \& laterals.

Drip or trickle, also called micro or localized irrigation is a pressurized system to irrigate the crops and orchards, consists of an extensive network of pipes usually of small diameters that deliver water directly to the soil near the plant. The system usually possesses fertilizer injection system, supplying plants with needed nutrients. In drip irrigation, the objective is to provide each plant with a continuous readily available supply of soil moisture, which is sufficient to meet transpiration demands. A filter is used to remove suspended materials, organic matter, sand and clay to reduce blockage of the emitters. Along with pumping station, control valves are installed to 
provide required pressure heads to the system.

The system contains emitters, laterals, manifold and mainline, which supplies water from the source to plant root zone. The mainline delivers water to manifold and manifold delivers water to laterals. The emitters, which are attached to laterals, distribute water to plant root zones. Laterals are normally made of polyethylene (PE) with diameters 12 to $20 \mathrm{~mm}$ in range, providing better flushing, easy installation and maintenance characteristics. Manifold and mainline are either in medium density polyethylene (PE) or rigid PVC with diameters 20 to $100 \mathrm{~mm}$ in range. Emitters are plant's point sources of water and designed to provide small and largely equal amount of discharges of plant requirement. Emitters are of many kinds, such as, orifices, nozzles, porous pipes, microtubes, etc. to dissipate the pressure in the pipe distribution networks by means of a narrow nozzle or long flow path, and thereby decreasing the water pressure to allow discharges of only a few litters per hour. Then, water is distributed by its normal movement through the soil profile. Plate 1.1 shows an example of a typical drip irrigation system consisting of emitters, laterals, manifolds, mainlines and filter equipments.

VISUAL BASIC (VB) is a high level programming language which evolved from the earlier DOS version called BASIC (Beginners' All-purpose Symbolic Instruction Code). The code looks a lot like English Language. Most people prefer to use Microsoft Visual Basic today, as it is a well-developed programming language and supporting resources are available everywhere.

In VB, programming is done in a graphical environment. However, in VB, one just needs to drag and drop any graphical object anywhere on the form, and you can change its color any time using the properties window. On the other hand, because the user may click on certain object randomly, each object has to be programmed independently to be able to respond to those actions (events). Therefore, a VB Program is made up of many subprograms, each has its own program code, and each can be executed independently and at the same time, each can be linked together in one way or another.

\section{MATERIALS AND METHODS}

\section{Calculation of Peak Water Requirement of Crop}

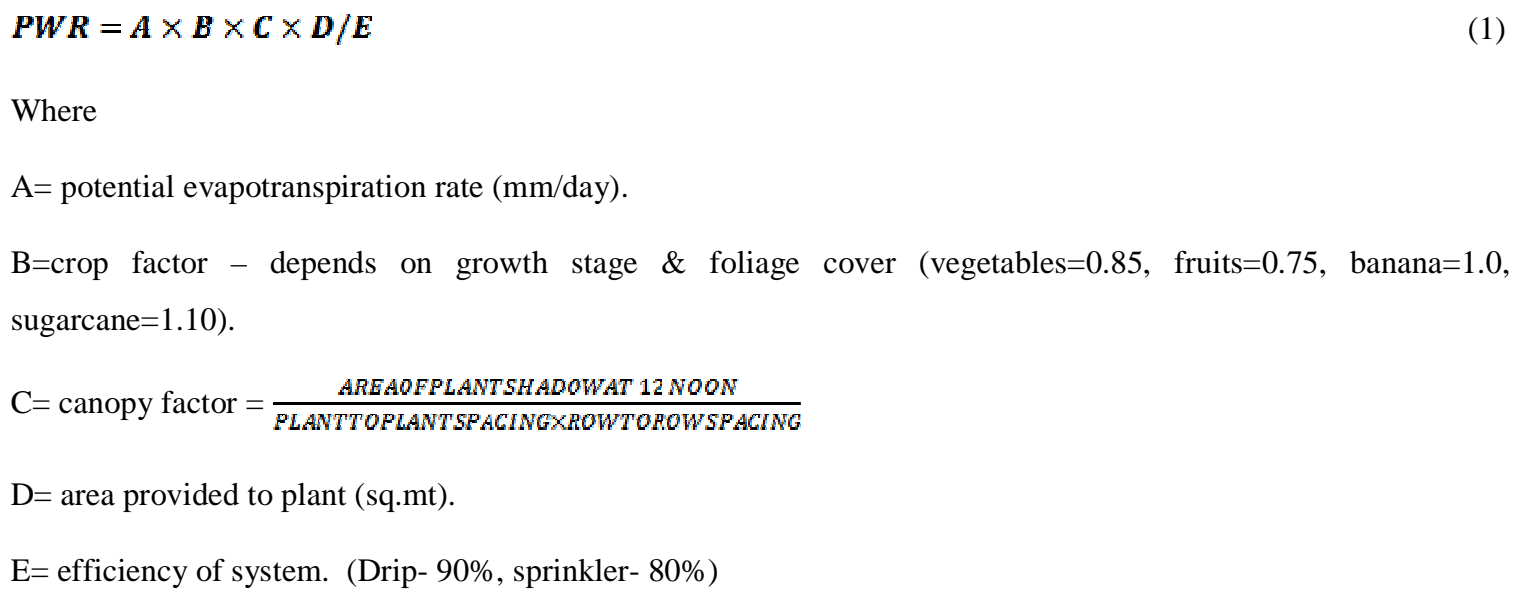

Where

\section{Selection of Dripper}

Table 3.1: Table for Selection of Drippers

\begin{tabular}{|l|l|}
\hline \multicolumn{1}{|c|}{ Type of Crop } & \multicolumn{1}{c|}{ Online (or) Inline } \\
\hline Water requirement & High discharge (or) low discharge \\
\hline
\end{tabular}




\begin{tabular}{|l|l|}
\hline \multicolumn{2}{|c|}{ Table 3.1: Contd } \\
\hline Soil type & High discharge (or) low discharge \\
\hline Land terrain (flat/hilly) & $\begin{array}{l}\text { Pressure compensating (or) non-pressure } \\
\text { compensating }\end{array}$ \\
\hline Maintenance & Openable (or) non-openable \\
\hline Cost & Standard (turbo key) (or) small (j-lock) \\
\hline
\end{tabular}

Water Application Rate

Water application rate $=$ no. of drippers per plant $\times$ dripper discharge

Irrigation time $=\begin{aligned} & \text { PEAK WATER REQUIREMENT } \\ & \text { WATER APPLICATION RATE }\end{aligned}$

No.of Irrigation Sections

No.of irrigation sections $=\begin{gathered}\text { NO.OFHOURSELECTRCITYAVAILSPLE } \\ \text { IRRIGATIONTIME }\end{gathered}$

Selection \& Design of Laterals

- Material :LLDPE (linear low density polyethylene)

- Diameter of material (or) laterals : size 12, 16, 20, 25, $32 \mathrm{~mm}$

- Length of lateral to be run depends on: $\mathrm{SDR}=$ specific discharge rate $(\mathrm{lph} / \mathrm{m})$

SDR of lateral $=\frac{\text { DRIPPERDISCHAFGE } \times \text { NO.OFDRIPPERPERPLANT }}{\text { PLANTTOPLANTSPACING }}$

Selection \& Design of Submain

- $\quad$ Material : PVC (or) HDPE

- $\quad$ SIZE : $40,50,63,75,90 \mathrm{~mm}$

SDR of Submain $=$ NO.OFPLANSCOVEREDBYSVBMAIN $\times$ DRIPPERDISCHARGEXNO.OFDRIPPERSPERPLANT

$\mathrm{SDR}=$ specific discharge rate $(1 \mathrm{ph} / \mathrm{m})$

Design \& Selection of Main Line

- $\quad$ Material : PVC (or) HDPE

- $\quad$ SIZE : $40,50,63,75,90 \mathrm{~mm}$

SDR of Main $=\frac{\text { NO.OFPLANSCOVERED BYSUBMAIN } \times \text { DRIPPERDISCHARGE } \times \text { NOOFDRIPPERSPERPLANT }}{3600}$

$\mathrm{SDR}=$ specific discharge rate $(\mathrm{lph})$

Selection of Filter \& Fertilizer Equipment

Filter capacity $=3.6 \times \boldsymbol{Q}($ main $) \quad\left(m^{3} / \mathrm{hr}\right)$

Design \& Selection of Pump

Table 3.2: Table for Design \& Selection of Pump

\begin{tabular}{|l|l|}
\hline Suction head & Vertical distance between water level to centre of pump \\
\hline
\end{tabular}




\begin{tabular}{|l|l|}
\hline \multicolumn{2}{|c|}{ Table 3.2: Contd } \\
\hline Delivery head & $\begin{array}{l}\text { Vertical distance between centre of pump to ground } \\
\text { level }\end{array}$ \\
\hline Frictional losses & $\begin{array}{l}\text { Frictional head losses in different types of filters, it is } \\
\text { assumed 2m for each type of filter. }\end{array}$ \\
\hline Main line losses & Frictional head losses occur in mainline \\
\hline Operating pressure & $\begin{array}{l}\text { In general 10m pressure is required for non pressure } \\
\text { compensating dripper and 15m for pressure } \\
\text { compensating dripper }\end{array}$ \\
\hline Fitting losses & $\begin{array}{l}\text { Loss in fittings like bends, elbows, tees, reducers, and } \\
\text { valves....etc. }\end{array}$ \\
\hline Elevation & $\begin{array}{l}\text { Pressure required to operate the ventury (or) fertilizer } \\
\text { applicator and is assumed to be 5m }\end{array}$ \\
\hline & $\begin{array}{l}\text { Vertical distance between ground level near to water } \\
\text { source to the highest level of ground }\end{array}$ \\
\hline
\end{tabular}

Total head required $=($ suction + delivery $)+$ head loss in filter + frictional head loss in main line + operating pressure + frictional head loss in fittings + ventury head + upward elevation if any

\section{HP Calculation}

$$
\mathrm{HP}=\frac{\mathrm{Q} \times H}{75 \times a \times b}
$$

(Source: Manual on Micro Irrigation Systems by Jain Irrigation Systems Ltd.)

Where; HP=horse power

$\mathrm{Q}=$ required discharge (lps)

$\mathrm{H}=$ required total head $(\mathrm{m})$

$\mathrm{a}=$ efficiency of motor (assumed 85\%)

$\mathrm{b}=$ efficiency of pump (assumed 80\%)

\section{Screen Shots of Software}

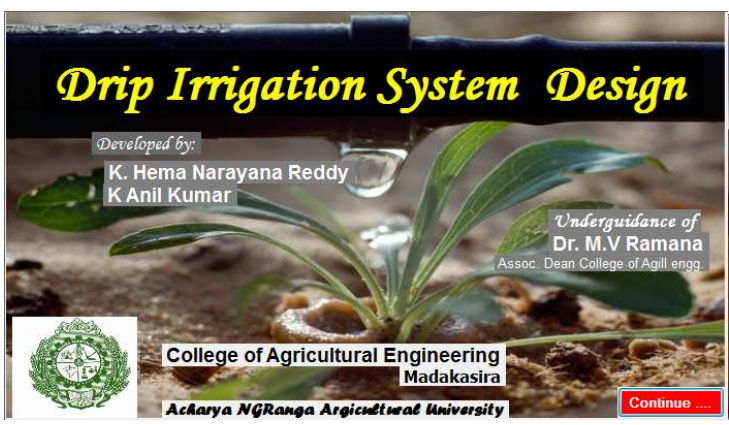

(1)

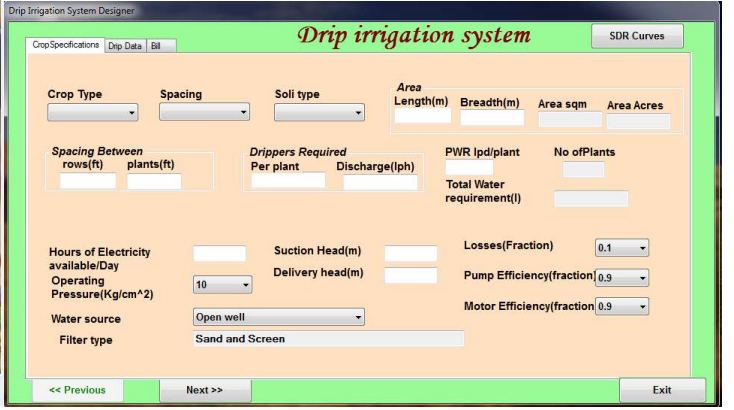

(2) 


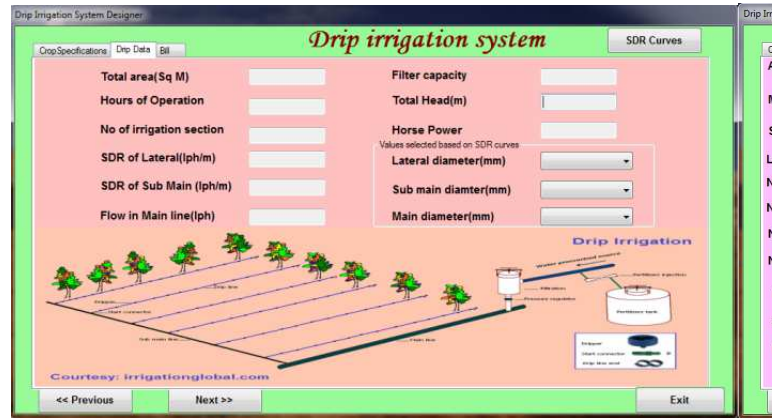

(3)

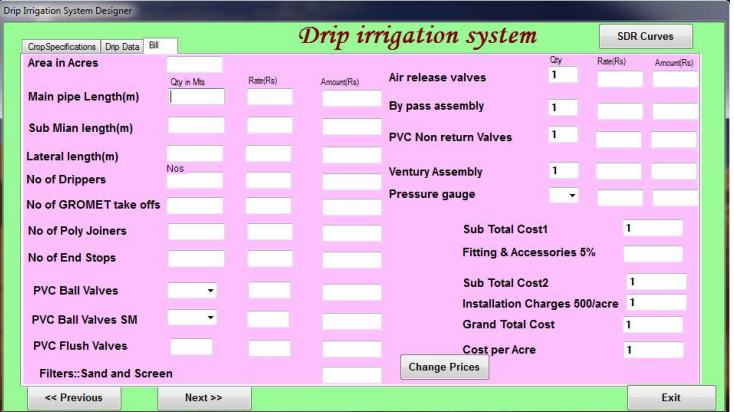

(4)

Figure: Screen Shots for Software

\section{RESULTS AND DISCUSSIONS}

Using the software developed, following reports were generated using samples problems and assumed data for major crops like Apple, Banana, Coconut, Mango, Pomegranate, Orange and the results were analyzed.

Software for the design and development of drip irrigation system was developed with visual basic software. A sample run was made with assumed data for different crops. The following as the summary of the results.

- For Apple crop with a spacing of $15 \mathrm{ft}$ x $15 \mathrm{ft}$ requires $1 \mathrm{hp}$ pump with total head of $38.5 \mathrm{~m}$ should be operated for $2.5 \mathrm{hrs}$, flow in main line is 2.116402 lph costs about 97009 Rs. per ha.

- For Banana crop with spacing of $10 \mathrm{ft} x 10 \mathrm{ft}$ requires $3 \mathrm{hp}$ pump with total head of $38.5 \mathrm{~m}$ should be operated for $1.25 \mathrm{hrs}$, flow in main line is 4.938272 lph costs about 120990 Rs. Per ha.

- For Coconut crop with spacing of $20 \mathrm{ft}$ x $20 \mathrm{ft}$ requires $1 \mathrm{hp}$ pump with total head of $38.5 \mathrm{~m}$ should be operated for $5 \mathrm{hrs}$, flow in main line is 1.20120 lph costs about 83417 Rs. Per ha.

- For Mango crop with spacing of $25 \mathrm{ft}$ x $25 \mathrm{ft}$ requires $1 \mathrm{hp}$ pump with total head of $38.5 \mathrm{~m}$ should be operated for $4.06 \mathrm{hrs}$, flow in main line is $1.532567 \mathrm{lph}$ costs about 77573 Rs. Per ha.

- For Pomegranate crop with spacing of $15 \mathrm{ft} \times 15 \mathrm{ft}$ requires $1 \mathrm{hp}$ pump with total head of $38.5 \mathrm{~m}$ should be operated for $2.5 \mathrm{hrs}$, flow in main line is 2.116402 lph costs about 120990 Rs. Per ha.

- For Orange crop with spacing of $18 \mathrm{ft} \times 18 \mathrm{ft}$ requires $2 \mathrm{hp}$ pump with total head of $38.5 \mathrm{~m}$ should be operated for $1.88 \mathrm{hrs}$, flow in main line is 2.962963 lph costs about 92940 Rs. Per ha.

This software can be run successfully depending on the situation and design can be made for different crops. This tool is very much useful for the technical people working in drip irrigation companies and allied fields.

\section{REFERENCES}

1. Eduardo, A., Holzapfel1, Alejandro, P., Lorite, I., Aureo, S., Silva de and Farkas, I. 2009. Design and management of irrigation systems. Chilean journal of agricultural research. 17-25.

2. Jyothipriya, A.N and Saravanabava, T.P. 2011. Design of Embedded Systems for Drip Irrigation Automation. International Journal of Engineering Science Invention. Vol (2), 34-37.

3. Mahir, D and Semih, O. 2011. A wireless application of drip irrigation automation supported by soil moisture sensors. Scientific Research and Essays. Vol. 6(7), pp. 1573-1582, 4

4. Michael, A.M. 2008. Irrigation theory and practice. Vikas publishing house. second edition. Page no: 653. 
5. Narayanan, R., Steele, D.D., Scherer, T.F. 2002. Computer model to optimize above ground drip irrigation systems for small areas. Journal of Applied Engineering in Agriculture. 18(4): 459-469.

6. Nazmeen Tamboli Pragati Tate Abhilasha Lokhande. Remote Drip Irrigation Control Using Internet. International Journal of Advanced Research in Computer Science and Software Engineering. Volume 3, Issue 12, December 2013. Page no: 908

7. Nilam, U and Khamkar. 2014. Design and Implementation of Expert System in Irrigation of Sugarcane: Conceptual Study. Sinhgad Institute of Management and Computer Application. Page no: 55.

8. Okorafor, O.O., Nzediegwu C., Egwuonwu C.C. and Duruanyim I.L. 2011. Design of a Drip Irrigation System for a Pineapple Orchard at the Federal University of Technology Owerri (F.U.T.O), School Farm. Greener Journal of Agricultural Sciences, Vol. 3(6), 502-507.

9. Oladipo and Adewumi, J.K. 2013. Computer Aided Drip Irrigation Design for Nigerian Agricultural Environment. 2: 638 doi:10.4172/scientificreports.

10. Rares and Halbac. 2009. Designing a drip irrigation system using hydrocalc irrigation planning. Research Journal of Agricultural Science, 41 (1). paper no: 420

11. Vishal Sharma and Ajay Pratap. 2011. Software Design of Water Supply System for Irrigation. International Journal of computer science and Information technology, 333-338.

\section{APPENDICES}

\section{Annexture - 1}

\section{General Peak Water Requirement for Different Crops}

\begin{tabular}{|l|c|c|c|c|c|}
\hline \multirow{2}{*}{ Crop } & $\begin{array}{c}\text { Spacing } \\
\text { (Row \& } \\
\text { Plant),ft }\end{array}$ & \multicolumn{2}{|c|}{ Drippers per plant * Discharge (lph) } & \multirow{2}{*}{$\begin{array}{c}\text { Peak water } \\
\text { requirement } \\
\text { (PWR) in lph }\end{array}$} \\
\cline { 3 - 5 } Grapes & $2 \times 4$ & $2 \times 4$ & $2 \times 4$ & $2 \times 4$ & 14 \\
& $2 \times 4$ & $2 \times 4$ & $2 \times 4$ & $2 \times 4$ & 16 \\
& $2 \times 4$ & $2 \times 4$ & $2 \times 4$ & $2 \times 4$ & 14 \\
\hline \multirow{2}{*}{ Pomegranate } & $12 \times 12$ & $3 \times 4$ & $3 \times 4$ & $3 \times 4$ & 24 \\
& $15 \times 15$ & $4 \times 4$ & $4 \times 4$ & $3 \times 4$ & 40 \\
\hline \multirow{2}{*}{ Guava } & $15 \times 15$ & $4 \times 4$ & $4 \times 4$ & $3 \times 4$ & 50 \\
& $18 \times 18$ & $4 \times 8$ & $4 \times 4$ & $4 \times 4$ & 60 \\
\hline Apple & $15 \times 15$ & $4 \times 4$ & $4 \times 4$ & $3 \times 4$ & 40 \\
\hline Orange & $18 \times 18$ & $4 \times 8$ & $4 \times 8$ & $4 \times 4$ & 60 \\
Lemon & $20 \times 20$ & $4 \times 8$ & $4 \times 8$ & $4 \times 8$ & 120 \\
\hline \multirow{2}{*}{ Mango } & $20 \times 20$ & $4 \times 8$ & $4 \times 8$ & $4 \times 8$ & 130 \\
\hline \multirow{2}{*}{ Banana } & $25 \times 25$ & $4 \times 8$ & $4 \times 8$ & $4 \times 8$ & 16 \\
& $5 \times 5$ & $1 \times 4$ & $1 \times 4$ & $1 \times 4$ & 20 \\
\hline Papaya & $7 \times 10$ & $2 \times 8$ & $2 \times 4$ & $2 \times 4$ & 80 \\
\hline \multirow{2}{*}{ Coconut } & $20 \times 20$ & $4 \times 4$ & $4 \times 4$ & $4 \times 4$ & 100 \\
& $25 \times 25$ & $4 \times 8$ & $4 \times 8$ & $4 \times 8$ & \\
\hline
\end{tabular}

General peak water requirement for different crops 


\section{ANNEXTURE - 2}

\section{SDR Curves}
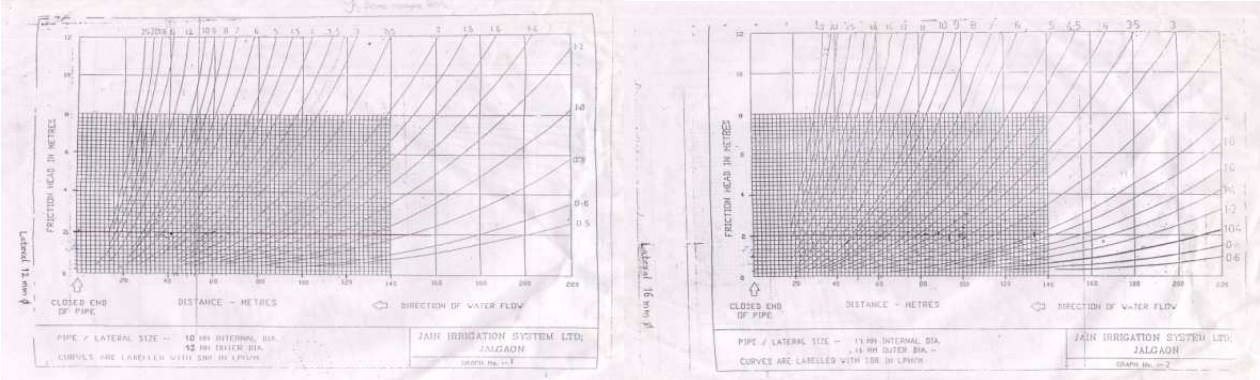

SDR Curves for 12mm Dia Lateralsdr Curves For 16mm Dia Lateral
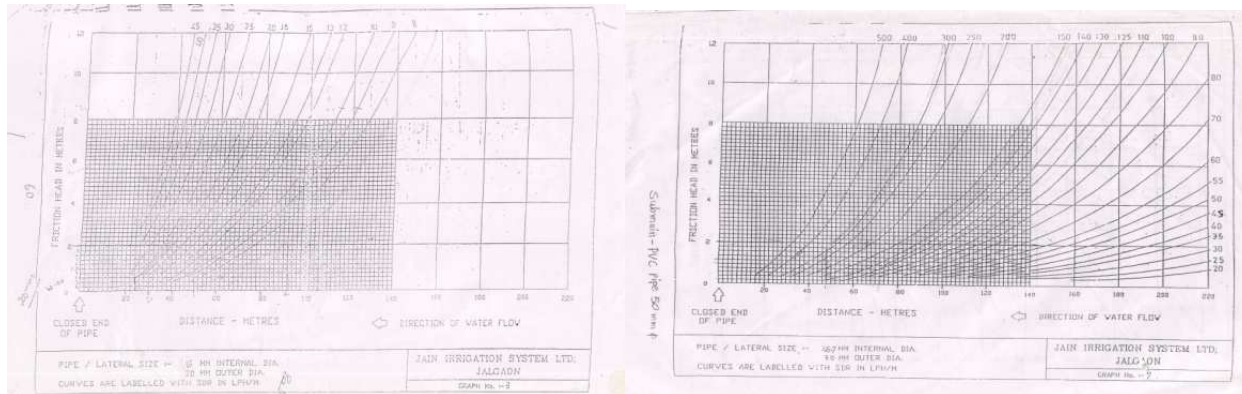

SDR curves for $20 \mathrm{~mm}$ dia lateralSDR curves for $50 \mathrm{~mm}$ dia PVC pipes
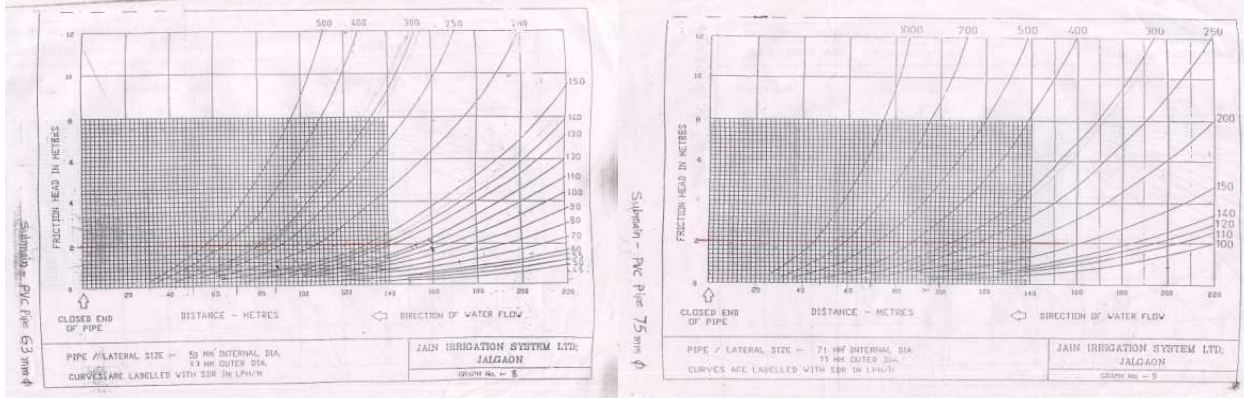

SDR curves for $63 \mathrm{~mm}$ dia PVC pipesSDR curves for $75 \mathrm{~mm}$ dia PVC pipes

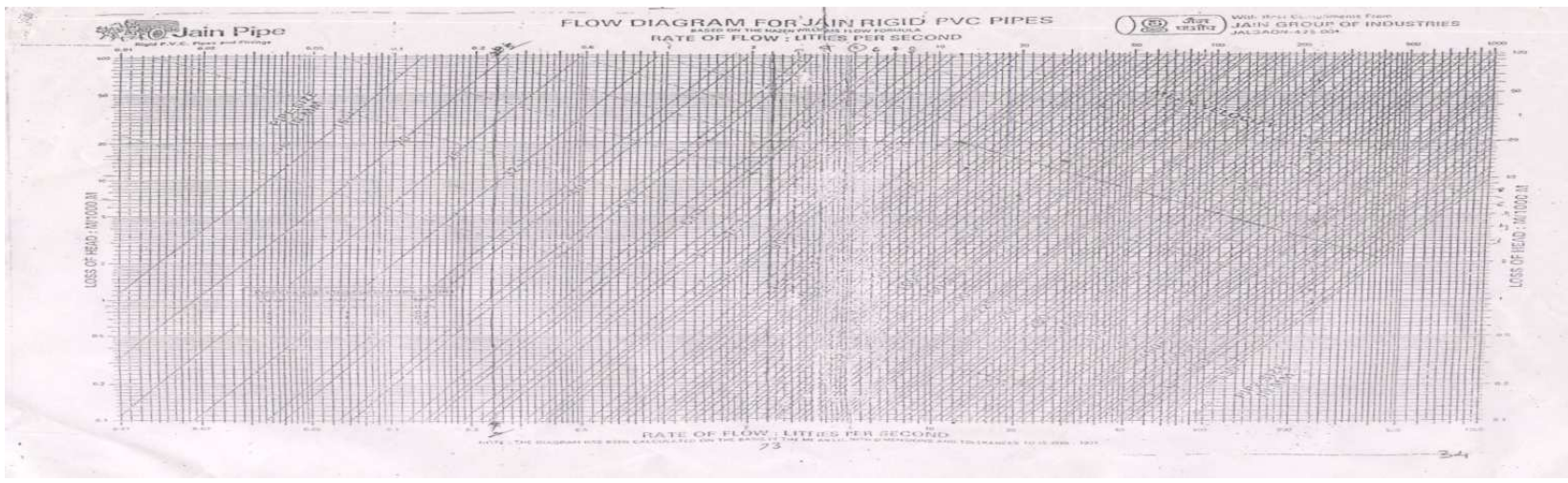

SDR curves for main line 


\section{ANNEXTURE - 3}

TABLE: Price List

\begin{tabular}{|c|c|c|}
\hline Item & Unit & Price \\
\hline $\begin{array}{l}\text { Pvc Pipes: } \\
\text { 90mm diameter } \\
75 \mathrm{~mm} \text { diameter } \\
63 \mathrm{~mm} \text { diameter } \\
50 \mathrm{~mm} \text { diameter }\end{array}$ & Metres & $\begin{array}{l}65.26 \\
46.59 \\
32.50 \\
30.67\end{array}$ \\
\hline $\begin{array}{l}\text { Laterals: } \\
\text { For } 20 \mathrm{~mm} \\
\text { diameter } \\
16 \mathrm{~mm} \text { diameter } \\
12 \mathrm{~mm} \text { diameter }\end{array}$ & Metres & $\begin{array}{l}6.7 \\
5.61 \\
4.6\end{array}$ \\
\hline $\begin{array}{l}\text { Pvc Ball valve: } \\
\text { For } 90 \mathrm{~mm} \\
\text { diameter } \\
75 \mathrm{~mm} \text { diameter } \\
63 \mathrm{~mm} \text { diameter } \\
50 \mathrm{~mm} \text { diameter } \\
20 \mathrm{~mm} \text { diameter }\end{array}$ & No's & $\begin{array}{l}1000 \\
911 \\
520 \\
337 \\
6.7\end{array}$ \\
\hline $\begin{array}{l}\text { Pvc Flush valves: } \\
\text { For } 90 \mathrm{~mm} \\
\text { diameter } \\
75 \mathrm{~mm} \text { diameter } \\
63 \mathrm{~mm} \text { diameter } \\
50 \mathrm{~mm} \text { diameter } \\
20 \mathrm{~mm} \text { diameter }\end{array}$ & No's & $\begin{array}{l}80 \\
72 \\
64 \\
60 \\
6.7\end{array}$ \\
\hline Drippers & No's & 2.30 \\
\hline End stops & No's & 1.77 \\
\hline Poly joiners & No's & 1.70 \\
\hline Gromett take off & No's & 1.33 \\
\hline Air release valve & No's & 337 \\
\hline By pass assembly & No's & 1254 \\
\hline $\begin{array}{l}\text { Pvc Non return } \\
\text { valve }\end{array}$ & No's & 374 \\
\hline Ventury assembly & No's & 1692 \\
\hline Pressure gauge & No's & 337 \\
\hline $\begin{array}{l}\text { Filters: } \\
\text { Sand filter } \\
\text { Screen filter } \\
\text { Hydro cyclone }\end{array}$ & No's & $\begin{array}{l}9400 \\
1474 \\
3867 \\
\end{array}$ \\
\hline
\end{tabular}

Table Price List

Total amount $=$ Add $5 \%$ to total amount $=$ Installation charge Rs.500/acre $=$

Grand total $=$ Cost $/$ acre 